\title{
SISTEM DEMOKRASI SEKULER TAK MENDUKUNG PENDIDIKAN BERKARAKTER
}

\author{
ROMIATY \\ Prodi. Bimbingan dan Konseling FKIP - UNPAR
}

\begin{abstract}
Abstraksi : Kondisi remaja saat ini sangat memprihatinkan, degradasi moral seperti tawuran pelajar, seks bebas, aborsi, narkoba dan lain sebagainya seakan menjadi suguhan sehari-hari. Salah satu upaya yang dilakukan oleh para pakar pendidikan untuk menangani permasalahan tersebut adalah dengan pendidikan berkarakter. Pendidikan berkarakter adalah Pendidikan untuk pembangunan karakter yang mencakup pengembangan substansi, proses dan suasana atau lingkungan yang menggugah, mendorong, dan memudahkan seseorang untuk mengembangkan kebiasaan baik dalam kehidupan sehari-hari. Agar terwujud pendidikan yang berkarakter maka peran negara sangatlah penting. Kebijakan- kebijakan yang di terapkan oleh Negara haruslah mendukung pembentukkan karakter yang baik pada remaja. Akan tetapi pada kenyataannya dalam sistem demokrasi sekuler kebijakankebijakan yang diambil sarat dengan berbagai kepentingan. Beberapa kebijakan yang tidak mendukung pembentukkan karakter antara lain; dalam menyikapi tawuran remaja diatur dalam Pasal 170 KUHP. Pasal ini mengandung kendala dan kontroversial tanpa memberikan efek jera. UU No 8/1992 tentang Perfilman, UU No 36/1999 tentang Telekomunikasi, UU No 40/1999 tentang Pers dan UU No 32/2002 tentang Penyiaran, yang mempermudah praktik seks bebas pada remaja dan RUU Kesetaraan dan Keadilan Gender (KKG) yang mempermudah praktik aborsi. Dan semua itu akan membuat pendidikan karakter di Indonesia hanya pada tataran teori dan sulit dalam pengaplikasiannya.
\end{abstract}

Keywords : Sistem Demokrasi, Pendidikan Karakter

Dunia pendidikan tercoreng kembali, korban tawuran antar pelajar dari tahun ke tahun mengalami peningkatan. Hal ini menambah deretan kasus panjang di dunia pendidikan Indonesia. Berbagai kajian ilmiah telah dilakukan oleh para pakar pendidikan untuk mencari solusi yang tepat bagi permasalahan dunia pendidikan. Tidak hanya tawuran antar pelajar, seks bebas, pengkonsumsi pornografi, aborsi, narkoba dan masih banyak lagi. 
Di zaman informasi dan teknologi saat ini, memudahkan untuk mengakses informasi tanpa filter. Maraknya suguhan informasi dari media cetak dan elektronik yang berisi pornografi juga turut memperburuk kondisi psikologis anak-anak bangsa.

Bagi sebuah bangsa dan Negara, anak adalah asset penting bagi kelangsungan suatu bangsa. Rusaknya perkembangan berpikir, emosional dan spiritualitas mereka saat ini akan membuat kerusakan pada suatu bangsa di masa yang akan datang. Penerus kepemimpinan yang akan mengayomi masyarakat akan semakin sulit untuk dicapai.

Berikut adalah data-data kerusakan remaja yang terjadi di Indonesia.

1. Data Komnas PA merilis jumlah tawuran pelajar tahun ini sebanyak 339 kasus dan memakan korban jiwa 82 orang. Tahun sebelumnya, jumlah tawuran antar-pelajar sebanyak 128 kasus.

Tak berbeda jauh, data dari Komisi Perlindungan Anak Indonesia (KPAI) menyebutkan, pengaduan kekerasan kepada anak sebanyak 107 kasus, dengan bentuk kekerasan seperti kekerasan fisik, kekerasan psikis, pembunuhan, dan penganiayaan. ${ }^{5}$

2. Zoy Amirin, pakar psikologi seksual dari Universitas Indonesia mengutip Sexual Behavior Survey 2011 yang menunjukkan 64 persen anak muda di kota-kota besar Indonesia „belajar ${ }^{\text {ee }}$ seks melalui film porno atau DVD bajakan. Akibatnya, 39 persen responden ABG usia 15-19 tahun sudah pernah berhubungan seksual, sisanya 61 persen berusia 20-25 tahun.

\footnotetext{
${ }^{5}$ http://ads3.kompasads.com/new diunduh 26/9/2012
} 
Survei yang didukung pabrik kondom Fiesta itu mewawancari 663 responden berusia 15-25 tahun tentang perilaku seksnya di Jabodetabek, Bandung, Yogyakarta, Surabaya dan Bali pada bulan Mei $2011 .^{6}$

3. Remaja puteri dikota-kota besar cenderung sudah tidak perawan. Hal ini berdasarkan hasil survei dari BKKBN yang menyatakan bahwa separuh dari perempuan lajang dikota besar khususnya Jabotabek kehilangan keperawanan dan melakukan hubungan seks pranikah. Tak sedikit pula yang hamil diluar nikah. Rentang usia yang melakukan seks pranikah berkisar $\begin{array}{lllll}\text { antara } & 13 & - & 18 & \text { tahun. }\end{array}$

Diwilayah lain di Indonesia seperti Surabaya perempuan lajang yang sudah kehilangan keperawanan mencapai 54 \%, Bandung 47 \%, dan Medan 52 \%. Data ini dikumpulkan BKKBN sepanjang kurun waktu tahun 2010. Senada dengan pernyataan Kepala BKKBN, Bpk. Sugiri Syarif "berdasarkan data yang kami himpun dari 100 orang remaja, 51

diantaranya sudah tidak lagi perawan". ${ }^{7}$

4. Berdasarkan data yang dikeluarkan BKKBN, diperkirakan setiap tahun jumlah aborsi di Indonesia mencapai 2,4 juta jiwa. Bahkan, 800 ribu di antaranya terjadi di kalangan remaja.

(Komnas PA) pada 2011 ada sekitar 2 juta tindak aborsi yang dilakukan pada tahun 2008. Dari jumlah tersebut, sekitar 62 persen lebih dilakukan oleh remaja. $^{8}$

\footnotetext{
${ }^{6}$ www.kepri.bkkbn.go.id diunduh pada tanggal 26/9/2012

7 www.jurnas.com/news diunduh pada tanggal 26/9/2012

${ }^{8}$ www.bkkbn.go.id diunduh pada tanggal 26/9/2012
} 
5. Anak-anak sudah banyak yang terlibat narkoba. Jumlah pecandu narkoba di Indonesia pada 2008 mencapai 3,6 juta orang. Rata-rata berada pada usia prodiktif 12 - 24 tahun. Di antara mereka yang telah mencoba narkoba, 80 persen menggunakannya di rumah sendiri dan 20 persen di rumah teman. Berdasarkan riset 100 persen pecandu narkoba adalah perokok dan juga mengkonsumsi alcohol. $^{9}$

\section{Pendidikan Karakter sebagai sebuah Alternatif Solusi}

Berbagai kajian ilmiah yang dilakukan oleh pakar pendidikan telah mencoba untuk memberikan alternatif solusi salah satunya adalah pendidikan karakter.

Pendidikan Karakter merupakan "keseluruhan disposisi kodrati dan disposisi yang telah dikuasai secara stabil yang mendefinisikan seorang individu dalam keseluruhan tata perilaku psikisnya yang menjadikannya tipikal dalam cara berpikir dan bertindak . Karakter dapat dipetakan dalam dua aspek penting dalam diri individu, yaitu kesatuan (cara bertindak yang koheren) dan stabilitas (kesatuan berkesinambungan dalam kurun waktu), karena itu ada proses strukturisasi psikologis dalam diri individu yang secara kodrati sifatnya reaktif terhadap lingkungan. Beberapa kriteria karakter seperti halnya: stabilitas pola perilaku, kesinambungan dalam waktu, koherensi cara berpikir dalam bertindak. Hal tersebut telah menarik perhatian serius para pendidik dan pakar ilmu pendidikan untuk memikirkannya dalam kerangka proses pendidikan karakter.

${ }^{9}$ www.bkkbn.go.id didunduh pada tanggal 26/9/2012 
Dengan demikian, pendidikan karakter merupakan dinamika pengembangan kemampuan yang berkesinambungan dalam diri manusia untuk mengadakan internalisasi nilai-nilai sehingga menghasilkan disposisi aktif, stabil dalam diri individu. Dinamika ini membuat pertumbuhan individu menjadi semakin utuh. Unsur-unsur ini menjadi dimensi yang menjiwai proses formasi setiap inividu. Jadi, karakter merupakan sebuah kondisi dinamis struktur antropologis individu yang tidak hanya sekedar berhenti atas determininasi kodratinya, melainkan sebuah usaha aktif untuk menjadi semakin integral mengatasi determinasi alam dalam dirinya semakin proses penyempurnaan dirinya (Koesoema, 2004:104). ${ }^{10}$

Pendidikan untuk pembangunan karakter pada dasarnya mencakup pengembangan substansi, proses dan suasana atau lingkungan yang menggugah, mendorong, dan memudahkan seseorang untuk mengembangkan kebiasaan baik dalam kehidupan sehari-hari. Kebiasaan ini timbul dan berkembang dengan didasari oleh kesadaran, keyakinan, kepekaan, dan sikap orang yang bersangkutan. Dengan demikian, karakter bersifat inside-out, dalam arti bahwa perilaku yang berkembang menjadi kebiasaan baik ini terjadi karena adanya dorongan dari dalam, bukan karena adanya paksaan dari luar (Raka,2007:6). ${ }^{6}$

Proses pembangunan karakter pada seseorang dipengaruhi oleh faktorfaktor khas yang ada pada orang yang bersangkutan yang sering juga disebut faktor bawaan (nature) dan lingkungan (nurture) di mana orang yang bersangkutan tumbuh dan berkembang. Namun demikian, perlu diingat bahwa faktor bawaan boleh dikatakan berada di luar jangkauan masyarakat untuk

\footnotetext{
${ }^{10}$ Siti Irene Astuti. D.,Dr, Laporan Penelitian implementasi Pendidikan KArakter ISBD,2010 http://staf.uny.ac.id/sites/default/penelitian
} 
mempengaruhinya. Hal yang berada dalam pengaruh kita, sebagai individu maupun bagian dari masyarakat, adalah faktor lingkungan. Jadi, dalam usaha pengembangan atau pembangunan karakter pada tataran individu dan masyarakat, fokus perhatian kita adalah pada faktor yang bisa kita pengaruhi atau lingkungan, yaitu pada pembentukan lingkungan. Dalam pembentukan lingkungan inilah peran lingkungan pendidikan menjadi sangat penting, bahkan sangat sentral, karena pada dasarnya karakter adalah kualitas pribadi seseorang yang terbentuk melalui proses belajar,baik belajar secara formal maupun informal (Raka,2007:7).

Karakter merupakan ciri dasar melalui mana pribadi itu terarah ke depan dalam membentuk dirinya secara penuh sebagai manusia apapun pengalaman psikologi yang dimilikinya. Dalam hal ini, pengembangan karakter merupakan proses yang terjadi secara terus-menerus, karakter bukan kenyataan melainkan keutuhan perilaku. Karakter bukanlah hasil atau produk melainkan usaha hidup. Usaha ini akan semakin efektif, ketika manusia melakukan apa yang menjadi kemampuan yang dimiliki oleh individu (Koesoema,2004:103). ${ }^{6}$

\section{Pendidikan Karakter Bukan Hanya Tanggung Jawab Sekolah}

Penekanan pendidikan karakter saat ini dititikberatkan pada peran sekolah sebagai suatu institusi formal yang berfungsi untuk membina dan mendidik siswa agar tidak hanya memiliki kemampuan ilmu pengetahuan dan teknologi (IPTEK) tetapi juga menjadi manusia yang beriman dan bertakwa (IMTAK). Di sekolah, guru adalah figur yang diharapkan mampu mendidik anak yang berkarakter, berbudaya, dan bermoral. Guru merupakan teladan bagi siswa dan memiliki peran yang sangat besar dalam pembentukan karakter siswa. Peran pendidik sebagai 
pembentuk generasi muda yang berkarakter sesuai UU Guru dan Dosen, UU No. 14 tahun 2005, guru didefinisikan sebagai pendidik profesional dengan tugas utama mendidik, mengajar, membimbing, mengarahkan, melatih, menilai, dan mengevaluasi peserta didik pada pendidikan anak usia dini jalur pendidikan formal, pendidikan dasar, dan pendidikan menengah.

Berbagai program mulai diterapkan disekolah, mulai dari peningkatan performa mengajar guru meliputi aspek kemampuan kognitif, keterampilan profesional dan keterampilan sosial (Slavin :1994), meningkatkan kesesuaian dan mutu pendidikan karakter yang dikembangkan oleh Kementerian Pendidikan Nasional. Kementerian Pendidikan Nasional mengembangkan grand design pendidikan karakter untuk setiap jalur, jenjang, dan jenis satuan pendidikan. Grand design menjadi rujukan konseptual dan operasional pengembangan, pelaksanaan, dan penilaian pada setiap jalur dan jenjang pendidikan. Konfigurasi karakter dalam konteks totalitas proses psikologis dan sosial-kultural tersebut dikelompokan dalam: Olah Hati (Spiritual and emotional development), Olah Pikir (intellectual development), Olah Raga dan Kinestetik (Physical and kinestetic development), dan Olah Rasa dan Karsa (Affective and Creativity development). Pengembangan dan implementasi pendidikan karakter perlu dilakukan dengan mengacu pada grand design tersebut. ${ }^{11}$

Akan tetapi pada kenyataannya beban berat dalam membentuk karakter siswa tidak dapat dilakukan oleh sekolah saja. Banyaknya tugas-tugas belajar

\footnotetext{
${ }^{11}$ Amin-x, contoh Makalah Pendidikan Karakter,2012 http://amin-x.blogspot.com/2012/07/contoh-makalah-pendidikan-karakter.html
} 
disekolah, kurangnya jam pelajaran agama, tingginya persaingan belajar antar siswa. Kondisi seperti ini tentu hanya akan melahirkan siswa yang ahli dalam ilmu pengetahuan dan teknologi saja tetapi miskin dalam iman dan takwa. Padahal iman dan takwa adalah modal penting dalam pembentukkan karakter siswa. Di tambah lagi, siswa mengikuti pendidikan di sekolah hanya sekitar 7 jam per hari, atau kurang dari 30\%. Selebihnya (70\%), peserta didik berada dalam keluarga dan lingkungan sekitarnya. Jika dilihat dari aspek kuantitas waktu, pendidikan di sekolah berkontribusi hanya sebesar 30\% terhadap hasil pendidikan peserta didik. Hal ini menunjukkan bahwa faktor keluarga dan lingkungan sebagai pendidikan informal siswa justu memberikan kontribusi yang sangat penting bagi terbentuknya karakter siswa $(70 \%)^{7}$

Walaupun keluarga dan lingkungan memberikan konstribusi yang signifikan dalam membentuk karakter siswa, akan tetapi pada kenyataannya permasalahan yang muncul di dunia pendidikan tidak kunjung terselesaikan. Kasuskasus kenakalan remaja semakin meningkat dari tahun ke tahun. Lalu apa yang menjadi akar permasalahannya?

\section{Sistem Demokrasi Sekuler sebagai Akar Permasalahan}

Sebab mendasar dari semua kebobrokan itu adalah diterapkannya sistem demokrasi sekuler. Salah satu esensi mendasar demokrasi adalah kedaulatan menjadi milik rakyat. Dalam ungkapan lain, menurut International Commision of Jurist dalam konferensinya di Bangkok, perumusan yang paling umum mengenai sistem politik demokratis adalah suatu bentuk pemerintahan dimana hak untuk 
membuat keputusan politik diselenggarakan oleh warga negara melalui wakilwakil yang dipilih oleh mereka dan yang bertanggung jawab kepada mereka melalui suatu proses pemilihan yang bebas (Budiardjo,2008). Namun demikian, itu baru dalam tataran teori. Dalam tataran praktiknya tidaklah demikian. Dalam Negara demokrasi, yang sering berlaku adalah hukum besi oligarki, yaitu sekelompok penguasa saling bekerja sama untuk menentukan kebijakan politik sosial dan ekonomi Negara tanpa harus menanyakan bagaimana aspirasi rakyat yang sebenarnya. ${ }^{12}$

Akhirnya tidak ada standar baku tentang benar salah. Semuanya dikembalikan kepada manusia dan kesepakatan diantara manusia. Disitulah lahir peraturan-peraturan yang sarat dengan kepentingan. Disamping, peraturan itu sendiri tidak baku bisa berubah mengikuti kehendak (wakil) rakyat. Sehingga aturan yang menjadi standar penyelesaian suatu masalah, tidaklah menyelesaikan masalah yang ada bahkan menambah masalah baru yang semakin tak terselesaikan.

Karena pemilik kedaulatan adalah manusia maka manusia memiliki kebebasan dalam segala hal. Pemahaman seperti ini juga telah mewarnai dalam kehidupan sosial kemasyarkatan. Paham kebebasan (liberalisme) yang menjadi salah satu pilar sistem sekuler demokrasi menjadikan pengaturan urusan manusia harus menjamin kebebasan manusia. Kebebasan itu tidak boleh dilanggar dan harus dijamin keberadaan dan pengekspresiannya. Sehingga peraturan dan

\footnotetext{
${ }^{12}$ Farid Wadjidi,Shiddiq Al-Jawi et.al. Ilusi Negara Demokrasi,2009, Al-Azhar Press, Bogor
} 
kebijakan politik yang dikeluarkan tidak boleh melanggar kebebasan ini. Lahirlah peraturan dan kebijakan yang bersifat permisif.

Selain itu dalam sistem sekuler demokrasi, aturan akhirnya menjadi semacam solusi kompromi atas persoalan yang ada dengan tetap menjamin kebebasan dasar yang dimiliki setiap orang (kebebasan berkeyakinan, berpendapat, berperilaku dan kepemilikan). Maka lahirlah peraturan yang menjamin dan memperbolehkan semua ekspresi kebebasan dengan batasan asal tidak melanggar kebebasan orang lain dan asal tidak mengganggu kepentingan umum. Dalam sistem sekuler demokrasi seperti ini, setiap orang boleh mengekspresikan hasrat seksualnya dengan siapa pun dengan cara apa pun selama suka sama suka dan tidak merugikan pihak lain. Dan itulah yang dilegalkan dalam

sistem hukum yang ada. ${ }^{13}$

Permasalahan yang terjadi pada siswa saat ini juga tidak terlepas dari kebijakan-kebijakan yang di keluarkan oleh pemerintah yang menerapkan sistem kapitalisme. Dalam menyikapi tawuran remaja yang memakan korban, diatur dalam Pasal 170 KUHP. Pasal ini berbunyi, ”Barang siapa terang-terangan dan dengan tenaga bersama menggunakan kekerasan terhadap orang atau barang diancam dengan pidana penjara paling lama lima tahun enam bulan”. Pasal ini mengandung kendala dan kontroversial. Subyek "barang siapa” menunjuk pelaku satu orang. Sementara istilah "dengan tenaga bersama” mengindikasikan suatu

\footnotetext{
${ }^{13}$ Hizbut Tahrir Indonesia, media Al-Islam edisi 617, Penerapan Syariah Islam Selamatkan Remaja dari Kenakalan dan Kriminalitas, 2012
} 
kelompok manusia. Delik itu, menurut penjelasannya, tak ditujukan pada kelompok yang tak turut melakukan kekerasan. Ancaman hanya ditujukan kepada yang benarbenar terbuka dan dengan tenaga bersama melakukan tawuran. Mengingat suatu kelompok massa, khususnya pelajar unik sifatnya, delik Pasal 170 sukar diterapkan karena banyak pelaku tawuran sebenarnya terlibat secara tak sengaja atau hanya ikut-ikutan dalam kerumunan.(kompas.com kompleksitas tawuran pelajar)Sehingga banyak siswa yang terjaring ketika melakukan tawuran hanya mendapat sangsi saja kemudian diberikan pengarahan lalu dibebaskan. ${ }^{14}$

Untuk mengatasi permasalahan seks bebas pada siswa Negara juga seolah menutup mata. Media cetak, media elektronik dan internet dibiarkan secara bebas untuk menyajikan pornografi. American Demographics Magazine dalam laporannya menyatakan bahwa jumlah situs pornografi meningkat dari 22.100 pada tahun 1997 menjadi 280.300 pada tahun 2000 atau melonjak 10 kali lebih dalam kurun waktu tiga tahun. Apabila dirata-rata, berarti setiap hari muncul 200- an lebih situs porno baru dan bisa dibayangkan berapa jumlahnya saat ini. Sementara Nathan Tabor, dalam artikelnya yang berjudul Adultary is killing the American Family mengatakan bahwa statistik menunjukkan bahwa $25 \%$ dari semua internet, mesin pencarinya minta dihubungkan dengan pornografi. ${ }^{15}$

Larangan pornografi sebenarnya telah diatur dalam hukum positif di Indonesia, diantaranya adalah dalam KUHP, UU No 8/1992 tentang Perfilman, UU No 36/1999 tentang Telekomunikasi, UU No 40/1999 tentang Pers dan UU No 32/2002 tentang Penyiaran. Namun pada tahap aplikasi, beberapa UU ini tidak

\footnotetext{
${ }^{14}$ Kompleksitas tawuran, www.kompas.com diunduh pada tanggal 26/9/2012

${ }^{15}$ Dwi Haryadi, S.H.,M.H.,Internet:Media Pendidikan atau Media Pornografi, http://www.ubb.ac.id/
} 
dapat bekerja dengan maksimal karena mengandung beberapa kelemahan dan kekurangan pada substansinya, yaitu perumusan melanggar kesusilaan yang bersifat abstrak/multitafsir, jurisdiksi yang bersifat territorial dan perumusan beberapa istilah dan pengertiannya yang tidak mencakup aktivitas pornografi di internet, sistem perumusan sanksi pidana yang tidak tepat dan jumlah sanksi pidana denda yang relatif kecil, sistem perumusan pertanggungjawaban pidana korporasi/badan hukum yang tidak jelas dan tidak rinci, dan tidak adanya harmonisasi tindak pidana dan kebijakan formulasi tindak pidana, baik pada tingkat nasional, regional maupun internasional. Adanya kelemahan-kelemahan ini menunjukkan perlu adanya amandemen bahkan pembaharuan hukum, agar hukum dapat menjangkau penjahat-penjahat di dunia maya. ${ }^{11}$

Dalam mengatasi masalah perilaku seks bebas di kalangan remaja. Kampanye safe sex with condom gencar dilaksanakan. Menteri Kesehatan Nafsiah Mboi dengan program kondomisasi remaja, hal ini untuk menekan penyebaran HIV/AIDS dikalangan remaja. Bertentangan dengan pendapat seorang pakar AIDS, R. Smith (1995) setelah bertahun-tahunmengikuti ancaman AIDS dan penggunaan kondom mengecam mereka yang telah menyebarkan safe sex dengan cara menggunakan kondom sebagai “sama saja dengan mengundang kematian”. Beliau juga berpendapat agar resiko penularan/penyebaran HIV/AIDS diberantas dengan cara menghindari hubungan seksual di luar nikah.

Kondomisasi bukan menghilangkan penyebaran HIV/AIDS tetapi secara tidak langsung melegalkan seks bebas. Hal ini pernah diungkapkan oleh Mark 
Schuster dari Rand, sebuah penelitian nirlaba dan seorang pediatric di University of California. Berdasarkan penelitian mereka, setelah kampanye kondomisasi, aktifitas seks bebas dikalangan pelajar pria meningkat dari 37\% menjadi 50\% dan dikalangan pelajar wanita meningkat dari $27 \%$ menjadi $32 \%{ }^{16}$

Praktik seks bebas yang dilakukan oleh remaja beresiko munculnya kehamilan yang tidak diinginkan dikalangan siswa. Untuk mengatasi kehamilan yang tidak diinginkan banyak siswi yang akhirnya melakukan tindakan aborsi. Ditambah lagi adanya RUU Kesetaraan dan Keadilan Gender (KKG) yang mempermudah praktik aborsi. Seperti yang tercantum pada Pasal 9 ayat (1) menyatakan kesempatan yang sama dan perlakuan yang adil dalam pemenuhan hak kesehatan reproduksi, hak pendidikan, hak ekonomi dan ketenagakerjaan, keterwakilan perempuan, perkawinan dan hubungan keluarga. Perempuan/remaja perempuan harus dijamin mendapatkan informasi dan pelayanan kesehatan seksual dan reproduksi, termasuk kemudahan mendapatkan kontrasepsi untuk mengurangi tingkat aborsi tidak aman dan kehamilan. ${ }^{17}$

Kasus-kasus aborsi yang direkam Komisi Nasional Perlindungan Anak Indonesia (KPAI) membuat kita miris. Kasus aborsi mulai 2008 hingga 2010 terus meningkat. Ironisnya, 62 persen pelakunya melibatkan anak-anak di bawah umur. Diperkirakan selama kurun waktu tersebut, kenaikan angka kasus aborsi rata-rata 15 persen setiap tahunnya. Pada 2008 ditemukan ada 2 juta jiwa anak

\footnotetext{
${ }^{16}$ Al-wai'e, Media Politik dan Dakwah,No.147 tahun XIII

${ }^{17}$ Hizbut Tahrir Indonesia, Buletin Dakwah Al-Islam edisi 602, RUU KKG bertentangan dengan Islam, Berbahaya dan Merusak, 2012
} 
korban aborsi. Tahun berikutnya, anak korban aborsi bertambah 300 ribu jiwa.

Pada 2010, bertambah lagi 200 ribu jiwa.

Kasus aborsi semakin mencolok di kota-kota besar. Yang paling mencengangkan adalah lebih dari separuh pelaku aborsi adalah anak di bawah umur. Anak-anak ini baru berumur kurang dari 18 tahun. Praktik aborsi yang paling dominan, dilakukan 37 persen pelakunya adalah dengan cara kuret atau pembersihan rahim, 25 persen melalui oral dengan meminum pil tertentu dan pijatan, 13 persen dengan cara suntik, dan 8 persen dengan cara memasukkan benda asing ke dalam rahim. Selain itu juga ada cara jamu dan akupuntur. ${ }^{18}$

\section{Penutup}

Pendidikan berkarakter akan tetap berjalan di tempat tanpa adanya dukungan dari Negara. Sistem demokrasi sekuler yang diusung oleh Indonesia saat ini memperburuk kondisi anak. Permasalahan-permasalahan yang ada tidak terselesaikan dan permasalahan baru akan segera bermunculan. Sebaik apapun program pendidikan yang dilaksanakan tanpa adanya kesinambungan dengan kebijakan pemerintah maka semua akan sia-sia. Hal ini menunjukkan bahwa sistem demokrasi sekuler tidak mendukung pembentukkan karakter pada siswa.

\section{Referensi}

Amin-x, contoh Makalah Pendidikan Karakter,2012

http://amin-x.blogspot.com/2012/07/contoh-makalah-pendidikan-

\footnotetext{
${ }^{18}$ DPD Hizbut Tahrir Indonesia Kalimantan Tengah, Mewaspadai Upaya Liberalisasi di balik Amandemen UU No.23/1992 tentang Kesehatan, 2005,Hizbut Tahrir Indonesia Kalimantan Tengah, Palangkaraya.
} 
karakter.html

Al-waiee, Media Politik dan Dakwah,No.147 tahun XIII

DPD Hizbut Tahrir Indonesia Kalimantan Tengah, Mewaspadai Upaya Liberalisasi

di balik Amandemen UU No.23/1992 tentang Kesehatan, 2005, Hizbut Tahrir Indonesia Kalimantan Tengah, Palangkaraya.

Dwi Haryadi, S.H.,M.H.,Internet:Media Pendidikan atau Media Pornografi, http://www.ubb.ac.id/

Farid Wadjidi,Shiddiq Al-Jawi et.al. Ilusi Negara Demokrasi,2009, Al-Azhar Press, Bogor

Hizbut Tahrir Indonesia, media Al-Islam edisi 617, Penerapan Syariah Islam Selamatkan Remaja dari Kenakalan dan Kriminalitas, 2012

Hizbut Tahrir Indonesia, Buletin Dakwah Al-Islam edisi 602, RUU KKG

Bertentangan dengan Islam, Berbahaya dan Merusak, 2012

Siti Irene Astuti. D.,Dr, Laporan Penelitian implementasi Pendidikan Karakter ISBD,2010, http://staf.uny.ac.id/sites/default/penelitian

http://ads3.kompasads.com/new

www.kompas.com, Kompleksitas tawuran, diunduh pada tanggal 26/9/2012

www.kepri.bkkbn.go.id diunduh pada tanggal 26/9/2012

www.jurnas.com/news diunduh pada tanggal 26/9/2012

www.bkkbn.go.id diunduh pada tanggal 26/9/2012

www.bkkbn.go.id didunduh pada tanggal 26/9/2012 